\title{
SUBMERGED MEMBRANE SYSTEM WITH BIOFILTER AS A TREATMENT TO
}

\section{RAINWATER}

N. Areerachakul ${ }^{1}$, M. Kitiphatmontree ${ }^{1}$, J Kandasamy², B. Kus ${ }^{2}$, C. Duangduen ${ }^{1}$, S. Pivsa -

$$
\text { Art }^{1} \text { and S Vigneswaran }{ }^{1^{*}}
$$

${ }^{1}$ Faculty of Science, Rajamangala University of Technology, Thanyaburi, Bangkok, Thailand.

${ }^{2}$ Faculty of Engineering and IT, University of Technology, Sydney, Broadway, NSW 2007, Australia

* corresponding author (Tel.: 612-95142641, Fax: 612-95142633, email: s.vigneswaran@uts.edu.au)

\begin{abstract}
Rainwater has been used as drinking water in Thailand for centuries especially in the rural parts and is accepted as an important water resource. From past to present, the quality of rainwater has changed with the land use of the landscape and its water quality is influenced by a diverse range of conditions such as the management of pollutant sources, the catchment condition, wind and meteorological conditions and the location of rainwater collection points. In this study, the quality of rainwater collected off roofs at several locations was examined. Granular activated carbon (GAC) filtration was used as a pretreatment to microfiltration to remove the dissolved organic matter (DOC). After an initial adsorption period, the biofilm that formed on the GAC (biofilter) was found to remove DOC by up to $40 \%, 35 \%$ and 15\% for bed filter depths of $15 \mathrm{~cm}, 10 \mathrm{~cm}$ and $5 \mathrm{~cm}$ respectively. Biofilters also removed nitrate and phosphate by more than $80 \%$ and $35 \%$. The hollow fibre membrane micro filtration with pore size of $0.1 \mu \mathrm{m}$ was used to treat the effluent from biofiltration to
\end{abstract}


remove the microorganisms/pathogens in the rainwater. Although there was no significant additional removal of DOC by MF, the biofilter removed all microorganisms. The use of biofilters as pretreatment to MF/UF could remove a higher amount of DOC, remove microorganisms, increase the membrane treatment efficiency, and reduce membrane fouling.

Keywords: Rainwater, characterization, biofilters, GAC, membrane filtration

\section{INTRODUCTION}

Rainwater has been used as drinking water in Thailand for centuries especially in the rural parts and is accepted as an important water resource. Roofs of households and buildings are the main catchment area to harvest rainwater for consumption. Thus, rainwater quality is liable to be contaminated from bird feces, microorganisms, dust, particulates from urban pollution, wind blow dust, pesticides, herbicides, dissolved organic gases $\left(\mathrm{CO}_{2}, \mathrm{NO}_{\mathrm{x}}, \mathrm{SO}_{\mathrm{x}}\right)$ from industries, vehicles, etc.

Yeo et al. (2006) studied a reuse system using membrane process treating rainwater runoff from an urban parking area in Korea, which contained non-point pollutants. The rainwater reuse system consisted of a pre-filter, membrane filter and disinfection. Hollow fibre membrane having pore size of $0.4 \mu \mathrm{m}$ made of polyvinylidne fluoride (PVDF) was used in this system because of its strength and ability in providing a stable flux. The treated water met all the parameters of the guideline values regulated by the Korean standard for reclaimed 
water. Turbidity was less than $0.3 \mathrm{NTU}$ in the final effluent. COD concentration decreased from $23.0 \mathrm{mg} / \mathrm{L}$ to $13.1 \mathrm{mg} / \mathrm{L}$ and $\mathrm{BOD}_{5}$ decreased from $5.3 \mathrm{mg} / \mathrm{L}$ to $1.7 \mathrm{mg} / \mathrm{L}$ after treatment by the pre-filter and membrane process. E. Coli was completely removed by this system (Yeo et al., 2006). However, membrane fouling was the major obstacle.

Heavy metals have recently become a concern as their concentration in rainwater tanks was found to exceed the recommended levels and therefore makes it unsuitable for human consumption (Magyar et al., 2007; Magyar et al., 2008; Han et al., 2006; Han et al; 2007). Rainwater storage tanks also accumulate contaminants and sediments that settle to the bottom of the tank.

Changes in $\mathrm{pH}$ may also occur in rainwater collected in tanks. Han et al. $(2006 ; 2007)$ reported the results of monitoring rainwater quality, such as $\mathrm{pH}$, turbidity, and metals, for a year, in the rainwater harvesting system at student dormitories at the Seoul National University, Korea. The pH of stored water changed to neutral over time, and turbidity and metal concentrations reduced through sedimentation over time. The $\mathrm{pH}$ of roof runoff and stored rainwater ranged from 6.5-9.0 and 6.8-8.4 respectively. It was weakly alkali but neutralised naturally in the storage tank. The turbidity of the stored rainwater showed a constant range of 1.29-2.35 NTU and metals were well within the Korean standards for drinking water. 
This study analyzed the water quality in rainwater collected at representative locations in Rajamangala University of Technology, Thanyaburi, Thailand in PVC tanks and in Ayudhaya Province, Thailand in clay rain jars. Water quality was characterised in terms of physical, chemical and organic parameters and compared against drinking water standards. The other objective of this study was to investigate the performance of biologically active granular activated carbon (biofilters) as a pretreatment to MF in terms of DOC removal and membrane fouling reduction.

\section{EXPERIMENTAL METHODOLOGY}

\section{Rainwater}

The rainwater samples used in these experiments were collected from 3 concrete roofs in PVC tanks at the Rajamangala University of Technology (RMUTT), Thanyaburi, Thailand and in clay jars at 5 locations in the Ayudhaya Province (Figure 1). The catchment area of the roofs had no noticeable leaves or debris in the guttering and none had first flush systems installed. First Flush systems divert the first part of the rainwater runoff from the roof before it the can the tank. However, birds were present which may have contaminated the rainwater by their dropping.

The $\mathrm{pH}$ of the rainwater samples were an average of 6.3 at $30^{\circ} \mathrm{C}$, and the conductivity was $78 \mu \mathrm{s} / \mathrm{cm}$ at $30{ }^{\circ} \mathrm{C}$. 


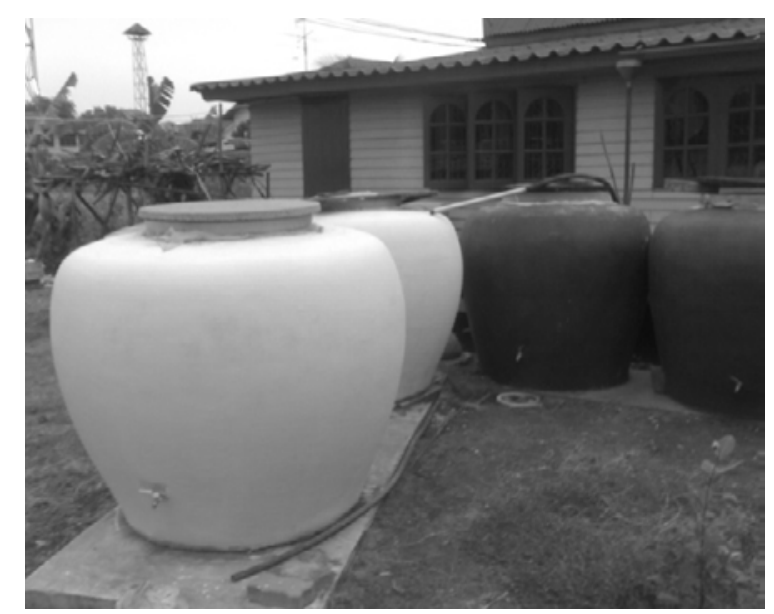

Figure 1 Rainwater Jar in Ayudhaya province

\section{Biofilters}

Biological adsorption experiments with granular activated carbon (GAC) were conducted in fixed bed columns. The physical properties of the GAC are shown in Table 1. The GAC was washed with distilled water then dried at $103^{\circ} \mathrm{C}$ and desiccated before use.

The experimental set up is shown in (Figure 2). The experiments were conducted using transparent acrylic filter columns with dimensions of $2 \mathrm{~cm}$ in diameter and $150 \mathrm{~cm}$ in length. The column had outlet pipes along its length and at the bottom of the column. The GAC was packed into the column to the required depth. The columns were operated in the downflow mode. Feed water was pumped from a water tank to the top of the columns and passed through the filter bed. An overflow outlet was placed above the filter bed to maintain a constant head above the GAC filter bed. Effluent samples were collected from the bottom of the column for analysis. Experiments were conducted with filtration velocity of $4 \mathrm{~m} / \mathrm{hr}$ with 
different bed depths of $5 \mathrm{~cm}, 10 \mathrm{~cm}$, and $15 \mathrm{~cm}$. The filters were backwashed for a period of 5 minutes once in two days to control excessive biofilm growth.

Table 1 Physical properties of GAC

\begin{tabular}{|l|c|}
\hline \multicolumn{1}{|c|}{ Specification } & $\begin{array}{c}\text { Estimated } \\
\text { Value }\end{array}$ \\
\hline Iodine number, mg /(g.min) & 800 \\
\hline Nominal size, m & $3 \times 10-4$ \\
\hline Maximum Moisture content & $5 \%$ \\
\hline Bulk density, kg/m3 & 748 \\
\hline BET surface area, m2/g & 748 \\
\hline
\end{tabular}

\section{Hollow fibre MF membrane}

The schematic diagram of the membrane filtration system is shown in Figure 3. Short term (6 hours) experiments were conducted with rainwater. The hollow fibre membrane (PVDF of $0.1 \mu \mathrm{m}$, Kolon membrane) was vertically submerged directly into a $10 \mathrm{~L}$ tank (Figure 3). The membrane length was $48.5 \mathrm{~cm}$ with a radius $2 \mathrm{~mm}$. The combined surface area of the hollow fibre membrane was $0.030486 \mathrm{~m}^{2}$. Constant flux experiments were conducted and the transmembrane pressure (TMP) was measured by a pressure sensor. The microfiltration unit was operated at $8 \mathrm{~L} / \mathrm{m}^{2} \mathrm{~h}$. 


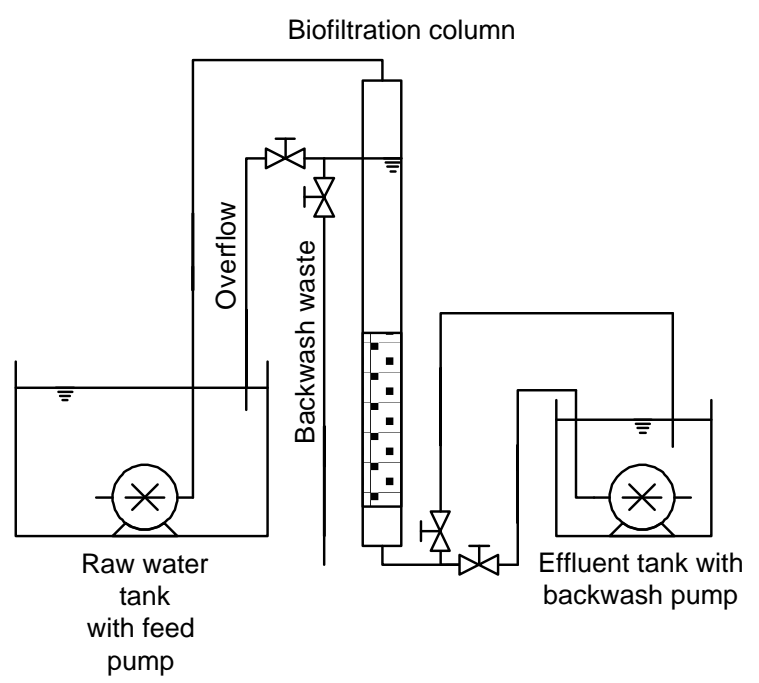

Figure 2 Biofilter experimental set up

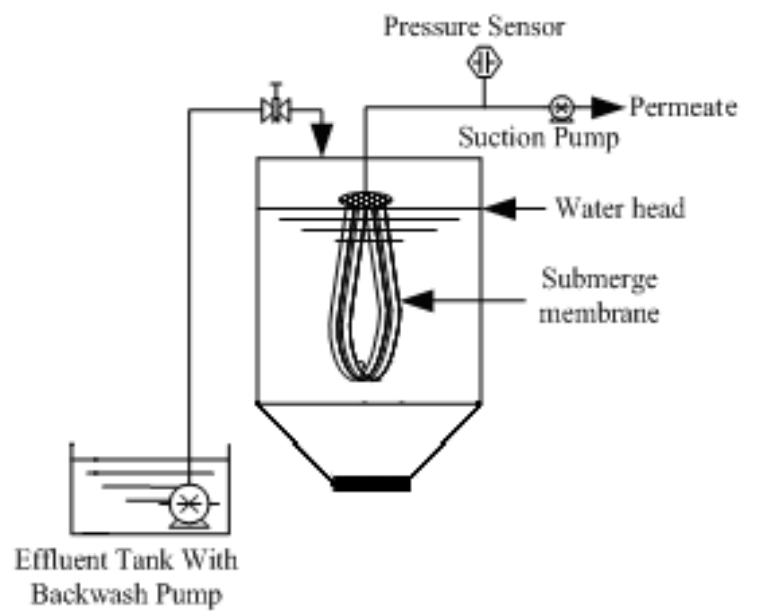

Figure 3 Schematic of submerge membrane set up

\section{Dissolved Organic Carbon (DOC)}

DOC was measured using a carbon analyser (TOC-V, Shimadzu, Japan). All samples were filtered through the $0.45 \mu \mathrm{m}$ membrane prior to the DOC measurement. 


\section{Water Quality Analysis}

Detailed laboratory analyses were carried out on the 8 rainwater storages to determine individual pollutants that exist in the rain water tanks. At each location, 10 samples were taken at different times. The pollutants analysed were heavy metals, mineral salts, nitrate, phosphate, sulphate, carbonate, total suspended solids, $\mathrm{pH}$, conductivity, hardness, turbidity. The testing methods are summarized in Table 2.

Table 2 - Water quality parameters and measurement methods (Eaton et al., 2005)

\begin{tabular}{|l|l|}
\hline Parameter & Measurement Method \\
\hline cadmium, chromium, copper, iron, lead, & Plasma - Mass Spectrometry \\
manganese, mercury, nickel, selenium, & \\
silver and zinc & \\
\hline Chloride & APHA 4500-CL ${ }^{-}$- G - Mercuric Thiocyanate \\
\hline Nitrate & Flow Injection Analysis \\
\hline potassium, sodium \& sulphate) & APHA 4500 NO3 - F - Automated Cadmium \\
\hline & Reduction Method \\
\hline
\end{tabular}




\begin{tabular}{|l|l|}
\hline $\mathrm{pH}$ & APHA 4500-H+ - Electronic Method \\
\hline Conductivity & APHA 2510-B - Laboratory Method \\
\hline Water hardness & Calcium \& Magnesium Calculation \\
\hline Turbidity & APHA 2130 - Nephelometric Method \\
\hline Total suspended solids & GFC equiv. filter- APHA 2540-D- Total \\
\hline Total dissolved salts & Suspended Solids Dried at $103^{\circ} \mathrm{C}-105^{\circ} \mathrm{C}$ \\
\hline Bicarbonates & Calculation using EC x 680 \\
\hline & Total Alkalinity - APHA 2320 - Titration \\
\hline
\end{tabular}

* APHA - American Public Health Association

\section{RESULTS AND DISCUSSION}

\section{Characterisation of Rainwater}

From Table 3, the results of rainwater characterization showed that the rain water in Ayudhaya has better quality of rainwater than in RMUTT (in terms of DOC, Total coliform, fecal coliform, heavy metal and mineral). These is because of the heavier pollution in the more urban area of Thanyaburi where RMUTT is located compared to Ayudhaya which is in the provinces and less urbanised. The results of testing shows the quality of the water in Ayudhaya meets many of the parametric standards specified in ADWS (2004). The 
concentrations of heavy metals were also at or below water quality standards (ADWS, 2004). However there is still a need for treatment methods to improve rainwater quality especially at RMUTT, Thanyaburi. The results also imply that diverting the first flush off the roof which is heavily polluted can improve the water quality of the rainwater collected in the tank.

In this study the submerged microfiltration was used to treat the rainwater collected from RMUTT with and without GAC biofilter as a pretreatment.

\section{BIOFILTER}

Figure 4 shows the DOC removal by the biofilters during the 3 months of operation. The DOC removal was 10\%, 25\%, and $40 \%$ with 5, 10 and $15 \mathrm{~cm}$ filter bed depth respectively. The removal rates in the early stages were relatively high due to the adsorption by granular activated carbon. However as the granular activated carbon became exhausted and as biological activity on the granular activated carbon increased a relatively steady removal rate, albeit with some fluctuation, in DOC was established. The biofilter operated under this steady condition for 70 days after an initial period of adsorption. The results show that the biofilter can remove organics for a prolonged period of time without the need to regenerate the activated carbon. 
It had been previously estimated that the approximate time for colonization of biomass into a steady state condition could take nearly three months (Cauchi et al., 1993). Figure 5 shows the biomass growth on GAC. During the first month the growth of the colonization using the indirect effluent measure of Hetrotropic Plate count (HPC) showed the colonization of microorganism was $400 \mathrm{CFU} / \mathrm{mL}$. It rose rapidly and after 90 days, the microorganism count was more than $3000 \mathrm{CFU} / \mathrm{mL}$. This may be due to the presence of first flush in the rainwater used in this study.

The growth of biomass on the GAC is shown in Figure 6. The Biomass growth in terms of colony count was not detected initially ( 0 day) and it increased to the third order $\left(10^{3} \mathrm{cfu} / \mathrm{gm}\right.$ GAC) after 30 days of operation and then to more than $10^{5} \mathrm{CFU} / \mathrm{g}$ GAC after 90 days of operation, Table 4. The biomass was taken from the GAC column by backwashing and GAC weight was calculate from bed height. The use of Gram's stain showed the colony had both Gram positive and Gram negative. However the colony was predominantly Gram positive and rod shape.

Table 3 Rainwater characterisation in various locations at Rajamangala University of Technology Thanyaburi (RMUTT) and at Ayudhaya province. 


\begin{tabular}{|c|c|c|c|}
\hline PARAMETER & 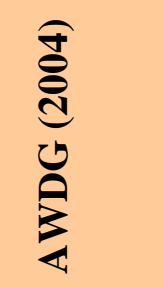 & 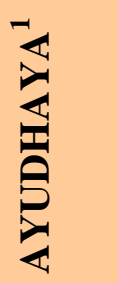 & 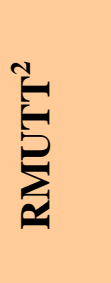 \\
\hline pH & $6.5-8.5$ & 6.4 & 6.7 \\
\hline CONDUCTIVITY (EC) (dS/m) & $<0.8$ & 0.082 & 0.78 \\
\hline $\begin{array}{l}\text { TOTAL DISSOLVED SALTS } \\
(\mathrm{mg} / \mathrm{L})\end{array}$ & & 55.31 & 160 \\
\hline $\begin{array}{l}\text { TOTAL SUSPENDED SOLIDS } \\
\qquad(\mathrm{mg} / \mathrm{L})\end{array}$ & & 400 & 428 \\
\hline TURBIDITY (NTU) & $<5$ & 5.07 & 42 \\
\hline $\begin{array}{l}\text { WATER HARDNESS (mg/L } \\
\mathrm{CaCO}_{3} \text { equivalent) }\end{array}$ & $<200$ & 47 & 59 \\
\hline NITRATE (mg/L N) & $<50$ & 14.1 & 18.6 \\
\hline CHLORIDE (MG/L) & $<400$ & 1.45 & 1.35 \\
\hline SULPHATE (MG/L) & $<400$ & 3.24 & 5.8 \\
\hline PHOSPHATE (MG/L) & & 0.86 & 1.5 \\
\hline CALCIUM (mg/L) & & 10.30 & 21.1 \\
\hline COPPER (mg/L) & $<2$ & 0.03 & 0.19 \\
\hline IRON (mg/L) & $<0.3$ & 0.54 & 0.875 \\
\hline MANGANESE (mg/L) & $<0.1$ & 0.001 & 0.006 \\
\hline
\end{tabular}




\begin{tabular}{|c|c|c|c|}
\hline LEAD (mg/L) & $<0.01$ & 0.017 & 0.174 \\
\hline ZINC (mg/L) & $<3$ & 0.15 & 0.19 \\
\hline ARSENIC (mg/L) & & ND & ND \\
\hline CADMIUM (mg/L) & & ND & ND \\
\hline Total coliform (MPN/100 mL) & $<2.2$ & 6.8 & $\geq 1000$ \\
\hline Fecal Coliform (MPN/ 100mL) & $<2.2$ & 6.8 & 920 \\
\hline E. Coli (MPN/100mL) & ND & 2 & 20 \\
\hline DOC & & 2.1 & 3.3 \\
\hline
\end{tabular}

$\mathrm{ND}=$ non-detectable

${ }^{1}$ Average of 10 samples at each of 3 locations at Ayudhaya

${ }^{2}$ Average of 10 samples at each of 5 locations at RMUTT

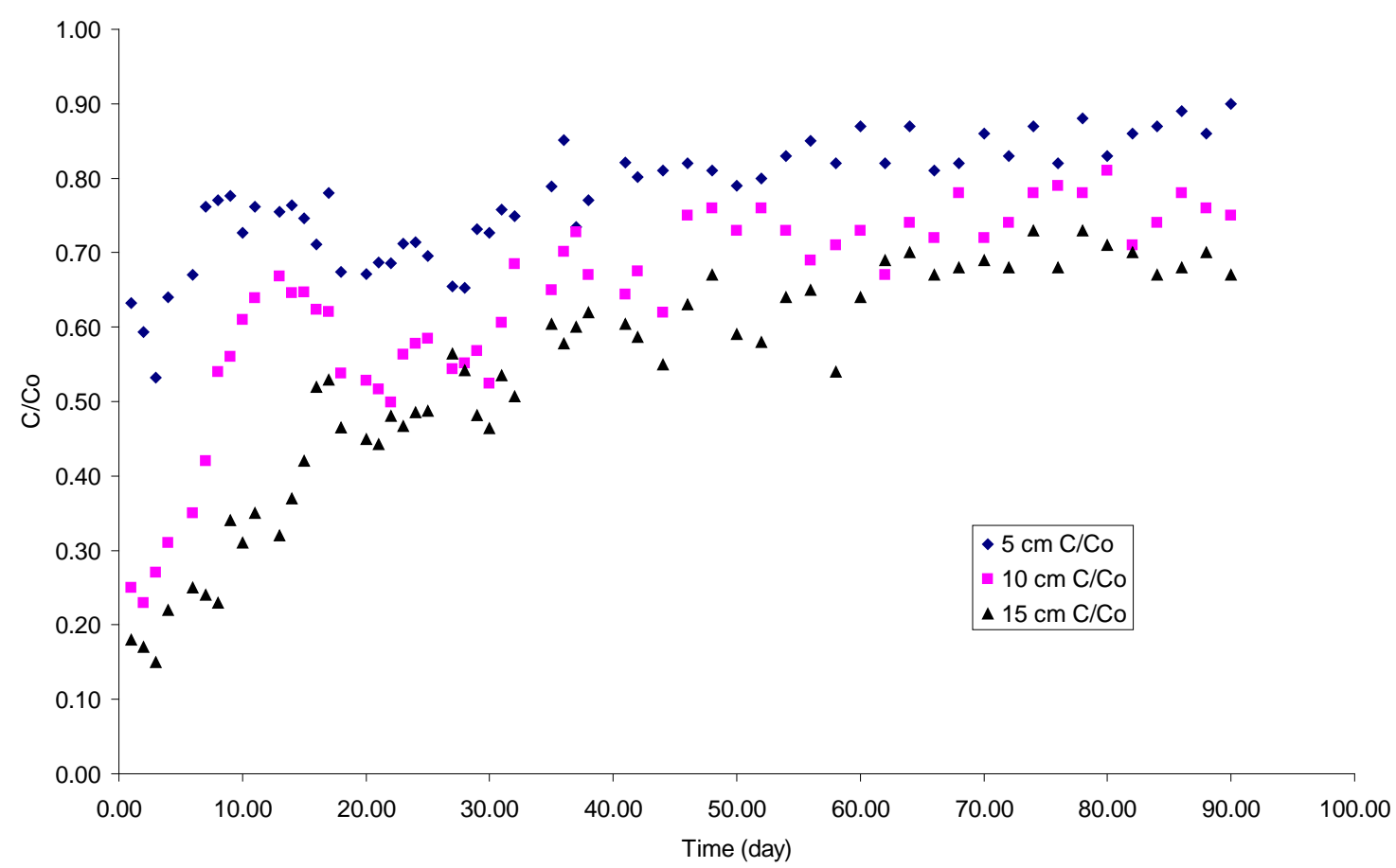

Figure 4. DOC removal with different BAC bed depth 5, 10, and $15 \mathrm{~cm}$. respectively with V 
$=4 \mathrm{~m} / \mathrm{h}$ (where $\mathrm{C}$ and $\mathrm{C}_{\mathrm{o}}$ are the effluent and influent DOC concentration).

Table 4 CFU count/g, GAC at different operation period of biofilter

\begin{tabular}{|c|c|c|c|c|c|}
\hline \multirow[t]{2}{*}{ Date } & \multirow[t]{2}{*}{ Dilution } & \multicolumn{2}{|c|}{ Colony count } & \multirow[t]{2}{*}{ Average } & \multirow[t]{2}{*}{ CFU/g.GAC } \\
\hline & & $\begin{array}{l}1 \\
\text { replication }\end{array}$ & $\begin{array}{l}2 \\
\text { replication }\end{array}$ & & \\
\hline \multirow[t]{5}{*}{0} & $10^{-1}$ & 3 & 5 & 4 & $<30$ \\
\hline & $10^{-2}$ & 0 & 2 & 1 & $<30$ \\
\hline & $10^{-3}$ & 0 & 0 & 0 & 0 \\
\hline & $10^{-4}$ & 0 & 0 & 0 & 0 \\
\hline & $10^{-5}$ & 0 & 0 & 0 & 0 \\
\hline \multirow[t]{5}{*}{30} & $10^{-1}$ & 291 & 289 & 290 & $2.9 \times 10^{3}$ \\
\hline & $10^{-2}$ & 70 & 56 & 68 & $0.68 \times 10^{3}$ \\
\hline & $10^{-3}$ & 2 & 17 & 8.5 & $<30$ \\
\hline & $10^{-4}$ & 3 & 13 & 8 & $<30$ \\
\hline & $10^{-5}$ & 0 & 0 & 0 & 0 \\
\hline \multirow[t]{5}{*}{90} & $10^{-1}$ & $>300$ & $>300$ & & \\
\hline & $10^{-2}$ & $>300$ & $>300$ & & \\
\hline & $10^{-3}$ & 127 & 169 & 148 & $1.48 \times 10^{5}$ \\
\hline & $10^{-4}$ & 14 & 9 & 11.5 & \\
\hline & $10^{-5}$ & 2 & 0 & 1 & \\
\hline
\end{tabular}




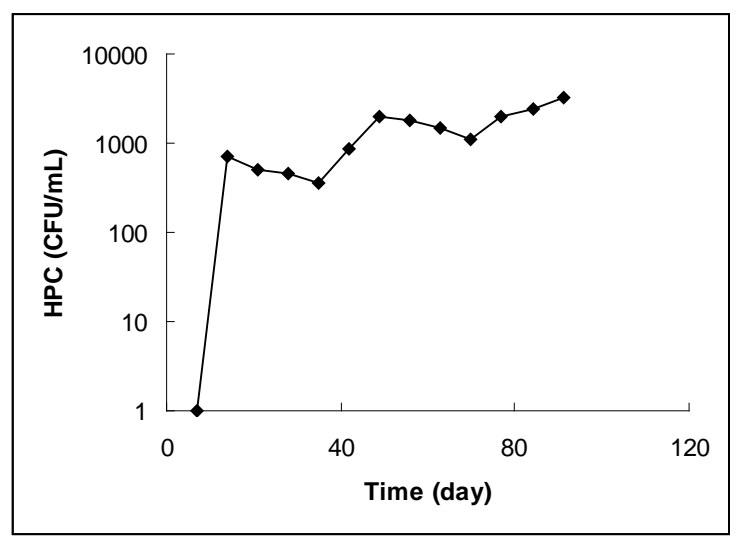

Figure 5 Increase in HPC pour plate (CFU/mL) as a function of time (day) with $15 \mathrm{~cm}$ bed depth and $\mathrm{v}=4 \mathrm{~m} / \mathrm{h}$

Daily samples of effluent from the biofilter taken after an operation time o f more than 1 month were tested for anion concentrations of $\mathrm{F}^{-}, \mathrm{Cl}^{-}, \mathrm{NO}_{3}{ }^{-}, \mathrm{SO}_{4}^{-}$, and $\mathrm{PO}_{4}{ }^{3-}$. Table 5 shows the results of these tests. The reduction of nitrate and phosphate was $80 \%$ and $30 \%$ respectively in the $10 \mathrm{~cm}$ filter bed depth, Table 5 . The reductions were much greater in the $15 \mathrm{~cm}$ filter bed. The reduction of $\mathrm{F}^{-}$and $\mathrm{Cl}$ was negligible as these anions were not consumed by the microbes in the biofilter.

MF

The MF alone achieved only a $10 \%$ removal of DOC with rainwater. When this was used with a pretreatment of biofiltration the DOC removal increased to 45-50\%. The majority of the DOC removal was by biofiltration which is about $40 \%$. However HPC analysis revealed that no bacteria were detected in the effluent water following membrane filtration. The 
microfiltration unit was operated at $8 \mathrm{~L} / \mathrm{m}^{2} \mathrm{~h}$ and the pressure development was almost negligible (less than $5 \mathrm{~Pa}$ ) during a filter run period of 6 hours.

Table 5. Average anion concentrations in the effluent of the biofilter. Samples were taken after a biofilter operation time of more than 1 month.

\begin{tabular}{|l|c|c|}
\hline Anion & $10 \mathrm{~cm}$ & $15 \mathrm{~cm}$ \\
& $\mathrm{mg} / \mathrm{L} \mathrm{( \%}$ & $\mathrm{mg} / \mathrm{L}(\%$ \\
& removal) & \\
\hline $\mathrm{F}^{-}$ & $0.0701(0 \%)$ & $0.0805(0 \%)$ \\
\hline $\mathrm{Cl}^{-}$ & $1.407(0 \%)$ & $1.253(0 \%)$ \\
\hline $\mathrm{NO}_{3}{ }^{-}$ & $3.451(81 \%)$ & $1.875(90 \%)$ \\
\hline $\mathrm{SO}_{4}{ }^{-}$ & $3.442(41 \%)$ & $3.214(44 \%)$ \\
\hline $\mathrm{PO}_{4}{ }^{3-}$ & $1.031(31 \%)$ & $0.805(46 \%)$ \\
\hline
\end{tabular}

\section{Fouling Index with Biofilter Effluent}

The two commonly used fouling indices namely SDI and MFI (Boerlage, 1998) were used to measure the membrane fouling reduction by the pretreatment of biofiltation. The SDI procedure is described in American Standards Testing and Methods (ASTM) D4189-95.

The MFI is an extension of the SDI and was developed by Schippers and Verdow (Schippers, 1980). The MFI can be used to predict the fouling potential of the feed in 
membrane systems and assumes that the particulate fouling of membranes is dominated by cake filtration. The MFI is determined from the gradient of the general cake filtration region for constant pressure in a plot of t/V versus V (Boerlage, 1998).

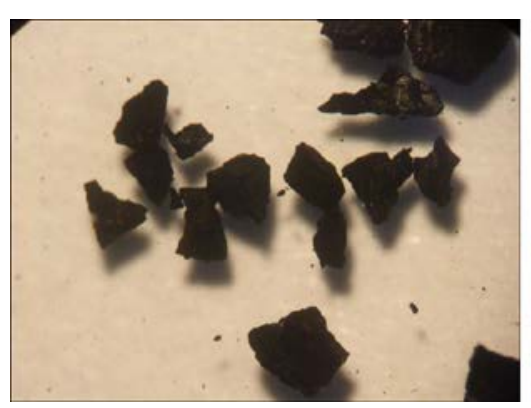

A. Pure GAC

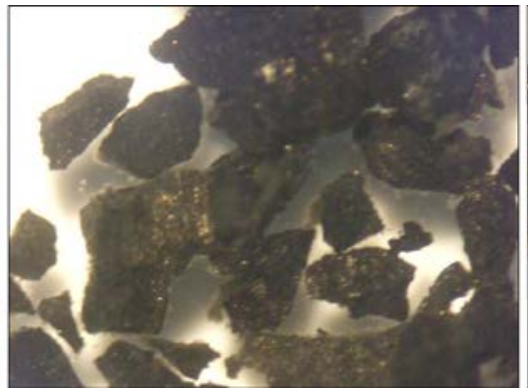

B. 30 days operation

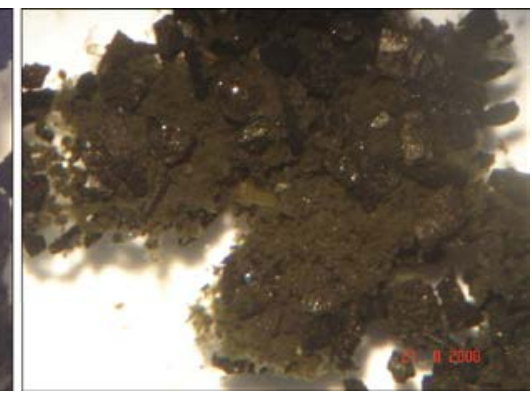

C 90 days of operation

Figure 6 Biomass growth on GAC in different period.

The MFI values with and without biofilter pretreatment were $360 \mathrm{~s} / \mathrm{L}^{2}$ and $863 \mathrm{~s} / \mathrm{L}^{2}$, respectively. The SDI values were also investigated. A pretreatment with biofilter decreased the SDI value from 6.2 to 4.1 . Thus, the biofilter as pretreatment to membrane filtration is effective in reducing membrane fouling potential.

\section{CONCLUSION}

The results of testing of samples of rainwater collected from roofs in Ayudhaya and in RMUTT, Thanyaburi, showed that although some parameters comply with water quality standards, there is still a need for treatment methods to improve rainwater quality. In this study various treatment methods were used and the results are summarized below; 
1. The initial DOC concentration of rainwater was $3.3 \mathrm{mg} / \mathrm{L}$ and contained nutrients such as nitrate, sulphate, phosphate at concentrations of 18.6, 5.8, and $1.5 \mathrm{mg} / \mathrm{l}$ respectively.

2. A GAC filter with a depth of $15 \mathrm{~cm}$ could remove up to $40 \%$ of DOC and could operate for at least for 3 months. It could remove a significant amount of nutrients such as nitrate and phosphate.

3. The use of MF/UF to filter the effluent of the biofilter showed only a marginal increase in DOC removal by another 5-15\% but it could effectively remove microorganisms from the effluent of the biofilter.

4. The MFI values decreased from $863 \mathrm{~s} / \mathrm{L}^{2}$ to $360 \mathrm{~s} / \mathrm{L}^{2}$ after biofilteration. The SDI values decreased from 6.2 to 4.1. The use of biofilters as pretreatment to MF could reduce membrane fouling in addition to removing a higher amount of DOC and increasing the membrane treatment efficiency.

\section{ACKNOWLEDGEMENT}

The research is funded by a grant form the Thailand Research Fund. Their support is gratefully acknowledged.

\section{REFERENCES}

1. ADWS (2004). Australian Drinking Water Guidelines, National Health and Medical Research Council, Australian Government, Australian Water Resources Council, Editor. 
2004. p. 615.

2. Boerlage, S. F. E., M. D. Kennedy, M. P. Aniye, E. M. Abogrean, G. Galjaard and J. C. Schippers (1998). Monitoring particulate fouling in membrane systems. Desalination 118: $131-142$.

3. Cauchi B., Billen G., Servais P. (1993). The elimination of biodegradable organic carbon in biological contactors - biological carbon filters. Water Supply, Vol. 11 No. 3/47, pp. 289 - 298

4. Eaton, A., Clesceri, L., Rice, E., Greenberg, A. (2005). Standard Methods for the Examination of Water \& Wastewater. Published jointly by: American Public Health Association, American Water Works Association, Water Environment Federation, 21st ed., 2005

5. Han, M.Y., Park, S., Kim, S. (2006). Analysis of Rainwater Quality in Rainwater Harvesting Systems at Dormitories in Seoul National University, Seoul, Korea, in IWA World Water Congress. 2006.

6. Han, M.Y., Mun, J.S. (2007). Particle behaviour consideration to maximize the settling capacity of rainwater storage tanks. Water Science \& Technology, 2007. 56(11): p. 7379.

7. Magyar, M.I., Mitchell, V.G, Ladson, A.R, Diaper, C. (2007). An investigation of rainwater tanks quality and sediment dynamics. Water Science \& Technology, 2007. 56(9): p. 21-28.

8. Magyar, M.I., Mitchell, V.G, Ladson, A.R, Diaper, C., (2008) Lead and other heavy metals common contaminants of rainwater tanks in Melbourne. Water Down Under 
Volume, 409 - 417 DOI: ISBN 0-858-25735-1

9. Schippers, J. C. and J. Verdow (1980). The modified fouling index: A method of determining the fouling characteristics of water. Desalination 32: 137-148.

10. Yeo, K.S., Kim, C.R., Dockko, S., (2006). Rainwater Reuse System Using Membrane Process in Urban Parking Area, RWHM Workshop, IWA $5^{\text {th }}$ World Water Congress and Exhibition, Beijing, China, pp 237- 242. 